\title{
THE COGNITIVE SHIFT IN TERMINOLOGY AND SPECIALIZED TRANSLATION
}

\author{
Pamela Faber Benítez \\ University of Granada
}

\begin{abstract}
This article offers a critical analysis and overview of terminology theories with special reference to scientific and technical translation. The study of specialized language is undergoing a cognitive shift, which is conducive to a greater emphasis on meaning as well as conceptual structures underlying texts and language in general. Terminology theory seems to be evolving from prescriptive to descriptive with a growing focus on the study of specialized language units from a social, linguistic and cognitive perspective. In consonance with this, new voices are beginning to be heard, which offer different and complementary perspectives on specialized language and translation.
\end{abstract}

\section{Resumen}

Este artículo propone un análisis crítico y una visión global de las teorías terminológicas con especial atención a la traducción científica y técnica. El estudio de los tecnolectos está sometido en la actualidad a un cambio hacia el cognitivismo, que a su vez conduce a un énfasis mucho mayor tanto en el significado como en las estructuras conceptuales que subyacen en los textos y en la lengua en general. La terminología parece estar pasando del prescriptivismo al descriptivismo, con un interés creciente por enfocar el estudio de las unidades de los tecnolectos desde una perspectiva social, lingüística y cognitiva. En esta misma línea, comienzan a oírse nuevas voces que ofrecen perspectivas diferentes y complementarias en torno a los tecnolectos y la traducción.

Keywords: Terminology. Scientific and tecnical translation. Cognitivism. Meaning. Descriptivism.

Palabras clave: Terminología. Traducción científica y técnica. Cognitivismo. Significado. Descriptivismo. 


\section{Introduction}

Terminology or specialized language is more than a technical or particular instance of general language. In today's society with its emphasis on science and technology, the way specialized knowledge concepts are named, structured, described, and translated has put terminology in the limelight.

The information in scientific and technical texts is encoded in terms or specialized knowledge units, which can be regarded as access points to more complex knowledge structures. As such, they only mark the tip of the iceberg. Beneath the waters stretch the tentacles of a many-splendored conceptual domain, which represents the implicit knowledge underlying the information in the text. In order to translate this type of specialized language text, translators must go beyond correspondences at the level of individual terms, and be able to establish interlinguistic references to entire knowledge structures. Only then can they achieve the level of understanding necessary to create an equivalent text in the target language.

\section{Specialized knowledge acquisition}

There has been a great deal of debate regarding how much a translator really needs to know about the specialized domain in order to translate a scientific or technical text. Some people even seem to believe that such texts should only be translated by experts in the field because in their opinion, it is impossible for translators to acquire the necessary expert knowledge.

Although it is not infrequent for experts with an acceptable level of a second language to try to translate texts because of their knowledge of terminological correspondences, they generally find that writing an article in another language is far from simple. In a parallel way, there are translators who believe that their syntactic and semantic knowledge of two languages guarantees an adequate translation of a scientific or technical text without any other previous preparation or documentation. Both enterprises are generally destined to failure.

The reason for this lies in the fact that knowledge of specialized language does not consist of a series of water-tight compartments. Terminological units and their correspondences possess both paradigmatic and syntagmatic structure. In other words, terms not only represent specialized concepts, but also have syntax and collocational patterns within general language. In this sense, merely knowing terminological correspondences is hardly sufficient since such units, when inserted in an appropriate (or inappropriate) context, create ripples that affect the text at all levels. However, for an acceptable 
understanding of the text, linguistic knowledge in itself is not sufficient either since a translator must also be aware of the types of conceptual entities that the text is referring to, the events that they are participating in, and how they are interrelated.

Generally speaking, it is quicker and more feasible to acquire knowledge of a specialized domain than knowledge of language, which is somewhat more complicated and takes considerably longer to master. However, this signifies that translators of specialized texts must also be closet terminologists and be capable of carrying out terminological management as a means of knowledge acquisition. This is one of the reasons why an understanding of terminology and specialized knowledge representation is a key factor in successful scientific and technical translation.

\section{Terminology as a discipline}

Terminology as a discipline of study is a relative newcomer. It arose from the need to facilitate specialized communication and translation, as well as knowledge transfer between text users belonging to different language communities and of similar as well as different knowledge levels. The theoretical proposals in this field have been mostly practice-based, arising from the elaboration of glossaries, specialized dictionaries and terminological and translation resources

As a subject field with explicit premises, terminology emerges from the need of technicians and scientists to unify the concepts and terms of their subject fields in order to facilitate professional communication and the transfer of knowledge (Cabré 2000a: 37).

Precisely for this reason, Terminology has been for some time a discipline in search of a theory with premises capable of accounting for specialized knowledge representation, category organization and description, as well as the semantic and syntactic behavior of terminological units in one or various languages. Over the years this quest for a set of theoretical principles has led terminologists to ask themselves inter alia whether Terminology should be regarded as a branch of Philosophy, Sociology, Cognitive Science, or Linguistics (to name a few).

Rather than say that Terminology may stem from any or all of them, we take the position that Terminology is essentially a linguistic and cognitive activity. In this sense terms are linguistic units which convey conceptual meaning within the framework of specialized knowledge texts. In the understanding of the nature of terms, this process of meaning transmission is as important as the concept that they designate. Terminological units are thus 
subject to linguistic analysis. Since this type of analysis can be carried out in a number of ways, it is necessary to choose the linguistic approach most in consonance with the object of study. Such an approach should be lexicallycentered and usage-based, as well as focus on meaning and conceptual representation. As we shall see, such is the case of cognitive linguistic approaches.

In the past, Terminology and Linguistics have mostly ignored each other. In its initial phase Terminology was interested in asserting its independence from other knowledge areas, and creating a totally independent discipline. This goal led terminologists to go to great lengths to emphasize differences between the two even to the extent of affirming that terms are not words.

In a parallel way, linguistic theory has largely ignored terminology, probably because specialized language has been and is often regarded as merely a special case of general language. Thus, it was not considered as worthy of serious study because anything pertaining to general language was also presumed to be true of specialized language.

However, interesting conclusions about specialized language, scientific translation, and language in general can be obtained when terminology is studied in its own right. As such, it is most certainly susceptible to linguistic analysis within the framework of a linguistic model. Oddly enough, some years ago this seemingly innocuous affirmation would have caused quite a hue and cry in terminological circles. The reason for this was that the first approximations to terminology had normalization as a primary objective. Great pains were taken to strive for totally unambiguous communication through standardization. This signified univocity or one-to-one reference between term and concept. The fact that the majority of terms designate concepts that represent objects in a specialized knowledge field meant that such an objective seemed possible to achieve. Nevertheless, it soon became apparent that this was more a desideratum than a reality.

\section{Theories of Terminology}

As has often been observed, terminology is a word that can either begin with an upper or lower-case letter. When terminology begins with a small $t$, it refers to the units in any specialized knowledge field. When it begins with a large $T$, it refers to the study of specialized language. As a rule, terminology theories can be classified as either prescriptive or descriptive. General Terminology Theory (GTT), which has the virtue of being the first theoretical proposal in this area, is essentially prescriptive in nature. As shall be seen, the theories that subsequently arose in reaction to the GTT are descriptive, and show an increasing tendency to incorporate premises from cognitive linguistics since 
they focus on the social, communicative, and cognitive aspects of terminology. The vision that they offer is more realistic because they analyze terms as they actually are used and behave in texts. One might say that these new series are representative of a cognitive shift in terminology.

\subsection{General Terminology Theory (GTT)}

Terminology as a discipline began in the 1930's with Eugen Wüster, the author of The Machine Tool, an Interlingual Dictionary of Basic Concepts (Wüster 1968), a systematically organized French and English dictionary of standardized terms (with a German supplement) intended as a model for future technical dictionaries.

This multi-volume work inspired the GTT, and set out the initial set of principles for the compilation and description of terminological data with a view to the standardization of scientific language. The GTT was later developed in Vienna by Wüster's successors, who interpreted his ideas and carried on his work. Although for many years the GTT offered the only set of principles and premises for compiling terminological data, its rigid view of the semantics of terminological units projected a uniformly limited representation of specialized knowledge concepts without allowing for their multidimensional nature. Needless to say, the GTT did not even attempt to account for the syntax and pragmatics of specialized language, which was not regarded as relevant. In this sense, it could not be usefully applied to translation.

The GTT focused on specialized knowledge concepts for the description and organization of terminological information. Within this framework concepts were viewed as being separate from their linguistic designation (terms). Concepts were conceived as abstract cognitive entities that refer to objects in the real world, and terms were merely their linguistic labels.

As Terminology struggled to acquire a semi-independent status, a considerable amount of effort was invested in distinguishing specialized language from general language, and in distinguishing terms from words. This radical emphasis on differences often seemed to convey the idea that terms were not even language at all, but rather abstract symbols referring to concepts in the real world.

One of the basic assertions of General Terminology Theory (Wüster 1979; Felber 1984) is that terms in specialized language are inherently different from general language words because of the monosemic reference between terms and concepts. In other words, the general claim is that a term or a specialized language unit can be distinguished from a general language word by its single-meaning relationship with the specialized concept that it designates, 
and by the stability of the relationship between form and content in texts dealing with this concept (Pavel \& Nolet 2001: 19).

However, this is an extremely idealized vision of specialized communication. Even the most cursory examination of specialized language texts shows that terminological variation is quite frequent, and that such variation seems to stem from parameters of specialized communication, such as the knowledge and prestige of the speakers, text function, text content, etc. The same concept can often be designated by more than one term, and the same linguistic form can be used to refer to more than one concept. Furthermore, terms have distinctive syntactic projections, and can behave differently in texts, depending on their conceptual focus. This is something that happens in texts of all languages, and is a problem that translators inevitably have to deal with.

Since Wüster believed that the function of Terminology was to create and standardize names for concepts, syntax was not regarded as falling within the scope of Terminology. Within the context of this theory, Terminology was also exclusively synchronic, and the diachronic dimension of terms was not considered. Wüster's principal objectives (apud Cabré 2003: 173) were:

1. To eliminate ambiguity from technical languages by means of standardization of terminology in order to make them efficient tools of communication;

2. To convince all users of technical languages of the benefits of standardized terminology;

3. To establish terminology as a discipline for all practical purposes and to give it the status of a science.

Cabré (2000a: 169) rightly points out that Terminology has suffered from a lack of innovative theoretical contributions because until very recently, there has been little or no theoretical discussion or confrontation of opinions. Another possible reason for the slow development of terminology is the lack of interest shown by specialists in other areas of knowledge, such as Linguistics:

The fifth reason, which may explain the continued homogeneity of the established principles, is the lack of interest in terminology by specialists of other branches of science, for example linguistics, psychology, philosophy and history of science and even communication and discourse studies. For many years terminology saw itself as a simple practice for satisfying specific needs or as a field of knowledge whose signs had nothing to do with the signs of language.

However, the 1990s brought new proposals and ideas that paved the way to integrating Terminology into a wider social, communicative, and linguistic context. According to LHomme et al. 2003, examples of such approaches are socioterminology (Boulanger 1991; Guespin 1991; Gaudin1993, 2003), the 
Communicative Theory of Terminology (Cabré 2000ab, 2001ab, 2003; Cabré et al. 1998), and sociocognitive terminology (Temmerman 1997, 2000, 2001, 2006).

\subsection{Social and communicative terminology theories}

In the early 1990's socioterminology and Communicative Terminology Theory appear on the horizon as a reaction to the hegemony of the GTT. Both theories present a more realistic view of terminology since they base their description on how terms are actually used in communicative contexts. They describe terminological units in discourse and analyze the sociological and discourse conditions that give rise to different types of texts.

\subsubsection{Socioterminology}

Socioterminology, as proposed by Gaudin (1993) applies sociolinguistic principles to terminology theory, and accounts for terminological variation by identifying term variants against the backdrop of different usage contexts. Parameters of variation are based on the social and ethnic criteria in which communication among experts and specialists can produce different terms for the same concept and more than one concept for the same term. Gaudin (1993: 216) writes:

[...] c'est que la socioterminologie, pour peu qu'elle veuille dépasser les limites d'une terminologie 'greffière', doit replacer la genèse des termes, leur réception, leur acceptation mais aussi les causes de leur échec et les raisons de leur succès, au sein des pratiques langagières et sociales concrètes des hommes qui les emploient. Ces pratiques sont essentiellement celles qui s'exercent dans des sphères d'activité. C'est pourquoi la socioterminologie devait rencontrer les réflexions sur les liens qui se nouent entre travail et langage.

According to Pihkala (2001) the socioterminological approach focuses on the social and situational aspects of specialized language communication, which may affect expert communication and give rise to term variation. According to socioterminologists, standardization is a chimera since language is in constant change. Polysemy and synonymy are inevitably present in terminology and specialized texts, and the use of one term instead of another can reflect the knowledge, social and professional status of a group of users, as well as the power relationships between speakers. Terminological variation also points to the fact that concept systems and definitions are not static. This is a reality that any theory that aspires to explanatory adequacy must deal with. In this respect, socioterminology is closely linked to Gregory and Carroll's 
(1978: 3-4) characterization of linguistic variation according to use and user even though this reference is not explicitly mentioned.

Although socioterminology does not aspire to independent theoretical status, its importance resides in the fact that it opened the door for other descriptive theories of terminology, which also take social and communicative factors into account, and which base their theoretical principles on the way terms are used in specialized discourse.

\subsubsection{Communicative Theory of Terminology (CTT)}

Linguistics and Terminology began to draw closer to each other with the Communicative Theory of Terminology (CTT) (Cabré 1999, 2000ab, 2001ab, 2003; Cabré et al. 1998). This proposal is more ambitious than socioterminology, and endeavors to account for the complexity of specialized language units from a social, linguistic and cognitive perspective.

According to Cabré (2003), a theory of terminology should provide a methodological framework for the study of terminological units. She underlines the fact that specialized knowledge units are multidimensional, and have a cognitive component, a linguistic component, and a sociocommunicative component. In this respect, they behave like general language words. Their specificity resides in a series of cognitive, syntactic, and pragmatic constraints, which affirm their membership in a specialized domain.

In this sense, the CTT regards terminological units as "sets of conditions" (Cabré 2003: 184) derived from, inter alia, their particular knowledge area, conceptual structure, meaning, lexical and syntactic structure and valence, as well as the communicative context of specialized discourse.

Cabré (ibid.) proposes the Theory of the Doors, a metaphor representing the possible ways of accessing, analyzing, and understanding terminological units. She compares a terminological unit to a polyhedron, a three-dimensional solid figure with a varying number of facets. Similarly, a terminological unit can also be said to have three dimensions: a cognitive dimension, a linguistic dimension, and a communicative dimension. Each is a separate door through which terminological units can be accessed. Nonetheless, one's choice of door (or focus) does not entail a rejection of the other two perspectives, which continue to reside in the background. According to Cabré, the CTT approaches units through the language door, but always within the general context of specialized communication.

At this time the CTT is probably the best candidate to replace the General Theory of Terminology as a viable, working theory of terminology. It has led to a valuable body of research on different aspects of Terminology such as 
conceptual relations, terminological variation, term extraction, and the application of different linguistic models to terminology. This has helped terminology as a field to get its act together, and begin to question GTT premises, which previously were not open to doubt.

However, the CTT is not without its shortcomings. Despite its clear description of the nature of terminological units and the fact that it mentions a term's "syntactic structure and valence", the CTT avoids opting for any specific linguistic model. The relation of the CTT with Linguistics is more in the nature of a light flirtation with various models than a monogamous relationship with any one in particular.

Its view of conceptual semantics is also in need of clarification. Although in a very general way the CTT bases its semantics on conceptual representation, it is more than a little vague when it comes to explaining how such representations are created, what they look like, and what constraints they might have:

[...] specialised discourse presents an organised structure of knowledge. This structure could be represented as a conceptual map formed by nodes of knowledge, which can be represented by different types of units of expression, and by relations between these nodes (Cabré 2003: 189).

Within this framework, terminological units are recognized as such because they represent knowledge nodes of a structure, and have a special meaning in this structure. If these factors are the prerequisites for term status, then one would think that conceptual representation, knowledge structure or ontology, and category organization would be an extremely important part of the CTT. However, this does not seem to be the case.

Another area in need of clarification in the CTT is semantic meaning. According to this theory, a lexical unit is general by default and acquires a specialized meaning, when it appears in a specific type of discourse. A terminological unit is regarded to be the special meaning of a lexical unit since its meaning is extracted from the "set of information of a lexical unit" (Cabré 2003: 184). With this affirmation the CTT seems to be avoiding the question of what specialized meaning is, and what its components are. The only clue given is when Cabré (2003: 190) states that terminological meaning consists of a specific "selection of semantic features according to the conditions of every speech act", which seems to implicitly say that she is in favor of some type of semantic decomposition. However, this can only be a supposition because nothing is explicitly said about the semantic analysis of specialized language units. This is a rather comfortable and safe position because it shunts any decisions in this respect back into the realm of Lexical Semantics, where 
there is already considerable disagreement as to the nature of word meaning and how it should be analyzed.

\subsection{Cognitive-based theories of Terminology}

Over the last decade linguistic theory seems to be in the process of undergoing something of a cognitive shift (Evans \& Green 2006), which has led it to increasingly focus on the conceptual network underlying language. The fact that linguistic form cannot be analyzed as divorced from meaning has led linguists to begin to explore the interface between syntax and semantics (Faber $\&$ Mairal 1999). This trend is also happening in the area of terminology.

Cognitive-based terminology theories, though similar in some ways to the CTT, also differ from it. It is not an accident that such theories have arisen in the context of translation. Despite the fact that they also focus on terms in texts and discourse, they make an effort to integrate premises from cognitive linguistics and psychology in their accounts of category structure and concept description. Relevant proposals in this area are sociocognitive terminology (Temmerman 1997, 2000, 2006) and frame-based terminology (Faber et al. 2005, 2006, 2007)

\subsubsection{Sociocognitive Terminology}

Insights from cognitive semantics (e.g. prototype structure and metaphor) began to have an impact on terminology theory with the advent of sociocognitive terminology as proposed by Temmerman $(1997,2000)$. Sociocognitive terminology (Temmerman 2000) concentrates on the cognitive potential of terminology in domain-specific language and on terminological variation as related to verbal, situational and cognitive contexts in discourse and in a wide range of communicative environments (Temmerman et al. 2005)

Temmerman (2000: 16) criticizes General Terminology Theory, and offers examples from the life sciences to demonstrate that the basic principles of the GTT are unrealistic and incapable of describing or explaining specialized language as it is actually used in communicative situations such as specialized translation. The GTT premises that fall under fire are the following:

1. Concepts have a central role in regards to their linguistic designations.

2. Concepts and categories have clear-cut boundaries.

3. Terminographic definitions should always be intensional.

4. Monosemic reference is the rule in terminology, where there is a oneto-one correspondence between terms and concepts.

5. Specialized language can only be studied synchronically. 
Temmerman (2000) argues that these premises are not valid, and asserts that:

1. Language cannot be regarded as divorced from concepts since it plays a crucial role in the conception of categories.

2. Many categories have fuzzy boundaries and cannot be clearly defined.

3. Optimal definition structure and type should not be limited to only one mode and ultimately depends on the concept being defined.

4. Polysemy and synonymy frequently occur in specialized language, and must be included in any realistic terminological analysis.

5. Categories, concepts, as well as terms evolve over time and should be studied diachronically. In this sense, cognitive models play an important role in the development of new ideas.

This declaration of principles is the launching pad for sociocognitive terminology. This theory is also in consonance with both Gaudin's socioterminology and Cabrés Communicative Theory of Terminology since it is descriptive rather than prescriptive, and regards terms as the starting point for terminological analysis. However, in the same way as the other approaches, it has very little to say about the syntactic behavior of terms.

What makes sociocognitive terminology different from other theories is its emphasis on conceptual organization, and its focus on category structure from the perspective of cognitive linguistics approaches. While GTT concept systems are organized in terms of isa and partof conceptual relations, sociocognitive categories are said to have prototype structure, and conceptual representations initially take the form of cognitive models. Another significant difference is that sociocognitive terminology is perhaps the first approach to truly take on board the historical or diachronic dimension of terms

Temmerman $(1997,2001)$ analyzes three concepts from the same general domain of biology, and comes to the conclusion that only one of them can be adequately described by the methods of the GTT. The other two are much more susceptible to sociocognitive terminological methods. She claims that such methods give less prominence to traditional ways of defining concepts (generic term and differentiating features), and focus more on deriving term definitions from their use in text corpora. The way a concept is described may vary, depending on a number of different parameters e.g. the type of category being defined, the knowledge level of the text sender and the receiver, and the profile of the termbase user (Temmerman and Kerremans 2003).

Category structure is prototypical, and the representations of relations between concepts in this framework are in the form of idealized cognitive models (ICMs) of the sort proposed by cognitive linguistics. This model of 
categorization is based on Rosch's (1978) Prototype Theory, which uses degrees of typicality as the configurational pattern for conceptual categories or domains with little or no mention of their internal structure, the types of information contained, or the network formed. Nevertheless, the internal structure of conceptual categories is also important because this would presumably affect and constrain any type of interdomain mapping.

According to Prototype Theory, a conceptual map takes the form of a series of concentric circles with concepts placed intuitively either nearer or farther away from the prototypical center. However, neither prototypes nor idealized cognitive models provide a place for syntagmatic data. Nor do they solve the question of how to determine either the relevant prototypical center or the psychologically real schematic meaning within a concept. Clear disadvantages of such representations are the fact that: (1) they are totally unconstrained; (2) they are based on an open-ended inventory of conceptual relations; (3) the resulting ICM and/or prototypical category seems to be largely based on the intuition of the modeler.

Perhaps, the most interesting part of sociocognitive terminology is its focus on the study of terms and concepts from a diachronic perspective in reaction to the exclusively synchronic analysis of the GTT. For example, Temmerman et al. (2005) study the word splicing to identify the history of its meaning, particularly its evolution over time, its use by different cultural groups, and its presence in both general and specialized language. In this sense, the study supports the fact that metaphorical modeling is one of the mechanisms consciously or unconsciously used in the creation of scientific terms. The objective is to gain insight into cognition as it emerges from terms and descriptions in scientific publications.

More recently, sociocognitive terminology has also begun to focus on ontologies as a more viable way of implementing conceptual representations. This combination of terminology and ontology is called termontography. Termontography is a hybrid term, which is a combination of terminology, ontology, and terminography. Its objective is to link ontologies with multilingual terminological information, and to incorporate ontologies into terminological resources. Temmerman and Kerremans (2003) describe termontography as a multidisciplinary approach in which theories and methods for multilingual terminological analysis (Temmerman 2000) are combined with methods and guidelines for ontological analysis (Fernández et al. 1997; Sure and Studer 2003).

Termontography, as outlined by Temmerman, seems to owe a great deal to the work done by Ingrid Meyer (Meyer et al. 1992; Meyer \& McHaffie 1994; 
Meyer, Eck \& Skuce 1997; Bowker \& L'Homme 2004) who was one of the first terminologists to perceive that term bases would be even more useful if their organization bore some resemblance to the way concepts are represented in the mind:

...term banks would be more useful, and useful to a wider variety of people, eventually even machines, if they contained a richer and more structured conceptual component than they do at present. (Meyer, Bowker \& Eck 1992: 159).

When term bases become terminological knowledge bases, as conceived by Meyer, they enhance data because the concepts and designations are linked to each other by meaningful relationships. Although the traditional generic-specific and part-whole relationships are contemplated, there is a greater emphasis on other types of relationships that enrich the resulting knowledge structure, such as cause-effect, object-function, etc. (Bowker \& LHomme 2004). This opens the door to the multidimensional representation of concepts.

Within the socioterminological framework, Kerremans et al. (2004) state that before building a domain-specific conceptual model or ontology, it is necessary to have an excellent grasp of the categories and their existing interrelationships, independent of any culture or language in the domain of interest. Such categories are referred to as units of understanding (UoU). However, one might reasonably question the existence of "pure" UoUs, when language and culture permeate mental representations at all levels of conceptualization. And supposing that such language-independent entities actually do exist, one might well ask what form they would actually take.

Even though Termontography originated as a brainchild of sociocognitive terminology, over the last few years it seems to have evolved far beyond it to the extent that it now seems to have acquired a life of its own, and to have become a totally different entity. The sophisticated knowledge engineering techniques and ontology creation processes described in recent articles (e.g. Kerremans, Temmerman \& Zhao 2005) have little or no relation to the rather rudimentary cognitive model analysis first described by Temmerman (2001: 84-85). As it stands now, Termontography seems to have undergone a complete metamorphosis to the point of bearing little or no resemblance to the initial premises of sociocognitive terminology.

For example, the conceptual representations proposed are in the form of computer-implemented ontologies. No mention is made of prototypes, idealized cognitive models or radial categories, all of which seem to have been lost in the shuffle. This is not necessarily a bad thing since, if the truth be told, cognitive linguistics representations, with the possible exception of frames, 
do not work well in computer applications. Nevertheless, it is extremely difficult to reconcile the ontology engineering described in recent articles with the conceptual representation advocated in sociocognitive terminology. The examples of termontographic conceptual relations mentioned by Kerremans et al. (2004) (e.g. 'has_subtype' and 'is_kind_of') appear to be rather similar to generic-specific relations of the traditional sort, which sociocognitive terminology eschews.

This seems to point to the fact that prototypes, despite being a very seductive concept, are not viable as a mode of category organization because at the end of the day they depend on the subjective evaluation of the terminologist. It is impossible to define the exact nature of the center of prototypical categories or explain how degrees of prototypicality can be objectively measured.

Finally, as previously mentioned, in the same way as other terminology theories, sociocognitivism studiously avoids dealing with syntax. The reason for this is probably that any syntactic analysis, whether of general or specialized language, must be either explicitly or implicitly based on a syntactic theory, and so far terminology and syntax have generally had little or nothing to say about each other.

\subsubsection{Frame-based Terminology}

Frame-based terminology (Faber et al. 2005; Faber et al. 2006; Faber et al. 2007) is another very recent cognitive approach to terminology, which shares many of the same premises as the CTT and sociocognitive terminology. For example, it also maintains that trying to find a distinction between terms and words is no longer fruitful or even viable, and that the best way to study specialized knowledge units is by studying their behavior in texts. Because the general function of specialized language texts is the transmission of knowledge, such texts tend to conform to templates in order to facilitate understanding, and are also generally characterized by a greater repetition than usual of terms, phrases, sentences, and even full paragraphs. This is something that specialized translators capitalize on when they use translation memories. Scientific and technical texts are usually terminology-rich because of the quantity of specialized language units in them, and they also are distinctive insofar as the syntactic constructions used.

Specialized language units are mostly represented by compound nominal forms that are used within a scientific or technical field, and have meanings specific of this field as well as a syntactic valence or combinatory value. Naturally, such noun phrases have configurations that may vary from language to language. The heavy concentration of such units in these texts points to 
the specific activation of sectors of domain-specific knowledge. As a result, understanding a terminology-rich text requires knowledge of the domain, the concepts within it, the propositional relations within the text, as well as the conceptual relations between concepts within the domain. This is the first step towards creating an acceptable target language text. All of these elements are targeted by frame-based terminology.

\subsubsection{Conceptual categories and category design}

As its name implies, frame-based terminology uses Fillmore's Frames (Fillmore 1976, 1982, 1985; Fillmore \& Atkins 1992) to structure specialized domains and create non-language-specific representations. Such configurations are the conceptual meaning underlying specialized texts in different languages, and thus facilitate specialized knowledge acquisition.

The concept of domains is problematic both in Terminology and Linguistics. The structure of categories of specialized concepts is and always has been a crucial issue in Terminology, precisely because the GTT opted for an onomasiological rather than a semasiological organization of terminological entries. However, in the type of conceptual representations proposed by the GTT, there is no effort made to create representations with explanatory adequacy from a psychological perspective.

Domains are also essential to the CTT and sociocognitive terminology. It is unfortunate that this focus has not as yet been accompanied by a systematic reflection on how to elaborate, design, and organize such a structure. For example, in even the best terminology manuals, the question of how to develop such configurations is never truly explained, and as a general rule, they are regarded as a product of the terminologist's intuition, which is afterwards validated by consultation with experts.

Regarding conceptual domains, in Terminology there seem to be two views on the matter, which are not necessarily incompatible with each other. A domain sometimes refers to the knowledge area itself, and other times, refers to the categories of concepts within the specialized field. Evidently, whether a domain is defined as one or the other has dramatic consequences for its internal structure.

If the concept of domain is ambiguous in Terminology, it is even more so in Linguistics. In many linguistic models, conceptual structure is not mentioned or even regarded as an issue. However, given the close relationship between language and thought, one would think that in order to better understand language, it would also be necessary to understand the concepts that linguistic forms designate. This is extremely important in any process of 
interlinguistic mediation, such as translation. In this sense, cognitive linguistic approaches have the virtue of regarding conceptual structure as a fundamental part of language and targeting this issue.

Indeed, the structure of categories is a recurrent topic, and in this sense there have been many proposals regarding their organization (Green \& Evans 2006). In the final analysis, however, the only consensus is that a category can be virtually anything. In addition, the structure of category members shows few if any constraints.

Although in all likelihood it is difficult to create a definitive inventory of conceptual categories and category design, it is possible to propose models that are somewhat less vague. More often than not, linguistics literature gives the impression that language only reflects a weary world of cups, birds, bachelors, and commercial transactions. What is needed is a model of categories and category structure that can be realistically applied to language on a broader scope.

Even though the notion of domain is central to cognitive linguistics, its indeterminacy is one of its most problematic aspects (Croft 1993: 339). Possibly, one way to begin to specify domains is to adhere to Goldberg's (1998: 205) view that the world is carved up into discretely classified event types, which correspond to Langacker's (1991: 294-298) conceptual archetypes. In this case, the organization of such event types would be semantic-based since syntax is not sufficient in itself to account for meaning differentiation (Mairal $\&$ Faber 2002).

Langacker (2000: 23) regards cognitive domains as conceptualizations of any type or degree of complexity, which represent the multiple realms of knowledge and experience evoked by linguistic expressions. The most prominent domains, which are the basis for linguistic meaning, would thus be those residing in the speaker's apprehension of the immediate context. This is in consonance with the concept of situated cognition, which is presently in vogue. However, this rather loose interpretation of a cognitive domain is conducive to an ad hoc specification by which domains are produced by linguistics in much the same way that a magician obligingly produces rabbits from a hat.

The model of categorization in Cognitive Linguistics and sociocognitive terminology is based on Rosch's (1978) Prototype Theory, which uses degrees of typicality as the configurational pattern for conceptual categories or domains. In much research, even though reference is often made to specific domains, little is said about their internal structure, the types of information contained, or the network formed. 
However, the internal structure of conceptual categories is also important because this would presumably affect and constrain any type of interdomain mapping. As previously mentioned, according to Prototype Theory, a conceptual map would be in the form of a series of concentric circles with concepts placed intuitively either nearer or father away from the center.

Geeraerts (1995) presents three major types of formal representations for conceptual domains: the radial set model popularized by Lakoff (1987), the schematic network as defined by Langacker (1987, 1991), and the overlapping sets model introduced by Geeraerts (1989). Despite the existence of superficial differences, he argues that these three modes are in reality, notational variants because all of them account for salience effects, metaphor and metonymy, hierarchical semantic links, and discrepancies between intuitive and analytical definitions of polysemy.

Nevertheless, the problem may very well lie in the analysis itself since none of the representational formats described explicitly provides a place for syntagmatic data. Nor do they solve the question of how to determine either the relevant prototypical center or the psychologically real schematic meaning within a concept. The specification of exactly how this should be done and the criteria motivating such decisions are never specified.

\subsubsection{Methodological foundations of Frame-based terminology}

Frames also fall within cognitive linguistic approaches, and are a type of cognitive structuring device based on experience that provide the background knowledge and motivation for the existence of words in a language as well as the way those words are used in discourse. However, frames have the advantage of making explicit both the potential semantic and syntactic behavior of specialized language units. This necessarily includes a description of conceptual relations as well as a term's combinatorial potential. Frame Semantics (Fillmore 1976, 1982, 1985; Fillmore \& Atkins 1992) and its practical application, the FrameNet Project (Fillmore \& Atkins 1998; Fillmore et al. 2003; Ruppenhofer et al. 2006), assert that in order to truly understand the meanings of words in a language, one must first have knowledge of the semantic frames or conceptual structures that underlie their usage. Evidently, the same can be said for specialized language units.

Frame-based terminology focuses on: (1) conceptual organization; (2) the multidimensional nature of terminological units; and (3) the extraction of semantic and syntactic information through the use of multilingual corpora. In frame-based terminology, conceptual networks are based on an underlying domain event, which generates templates for the actions and processes 
that take place in the specialized field as well as the entities that participate in them.

Our methodology is based on deriving the conceptual system of the domain by means of an integrated top-down and bottom-up approach. The bottom-up approach consists of extracting information from a corpus of texts in various languages, specifically related to the domain. Our top-down approach includes the information provided by specialized dictionaries and other reference material, complemented by the help of experts in the field.

In a parallel way, we specify the underlying conceptual framework of a knowledge-domain event (Faber \& Jiménez 2002; Faber et al. 2006). The most generic or base-level categories of a domain are configured in a prototypical domain event or action-environment interface (Barsalou 2003). This provides a template applicable to all levels of information structuring. In this way a structure is obtained which facilitates and enhances knowledge acquisition since the information in term entries is internally as well as externally coherent (Faber et al. 2007).

One of the basic premises of this approach is that the description of specialized domains is based on the events that generally take place in them, and can be represented accordingly (Grinev \& Klepalchenko 1999). Each knowledge area thus has its own event template (see figure 1). Accordingly, generic categories are configured in a domain event or action-environment interface (Barsalou 2003: 513; Faber et al. 2005), which provides a frame for the organization of more specific concepts. The specific concepts within each category are organized in a network where they are linked by both vertical (hierarchical) and horizontal (non-hierarchical) relations.

Accordingly, each subdomain within the event is characterized by a template with a prototypical set of conceptual relations. This logically places much emphasis on terminological definitions, which are regarded as miniknowledge representations or frames. Such definitions are not entered in a cut-and-paste fashion from other resources. Rather they are based on the data extracted from corpus analysis, which is the main source of paradigmatic and syntagmatic information about the term. This is evident in the following description of erosion.

For example, erosion is a process that conforms to the process template within the context of the Coastal Engineering Event. A process takes place over a period of time and can be divided into smaller segments or phases. It can happen at a specific season of the year, and may occur in a certain direction. It is induced by an agent (natural force) and affects a specific geographi- 


\section{The Coastal Engineering Event}

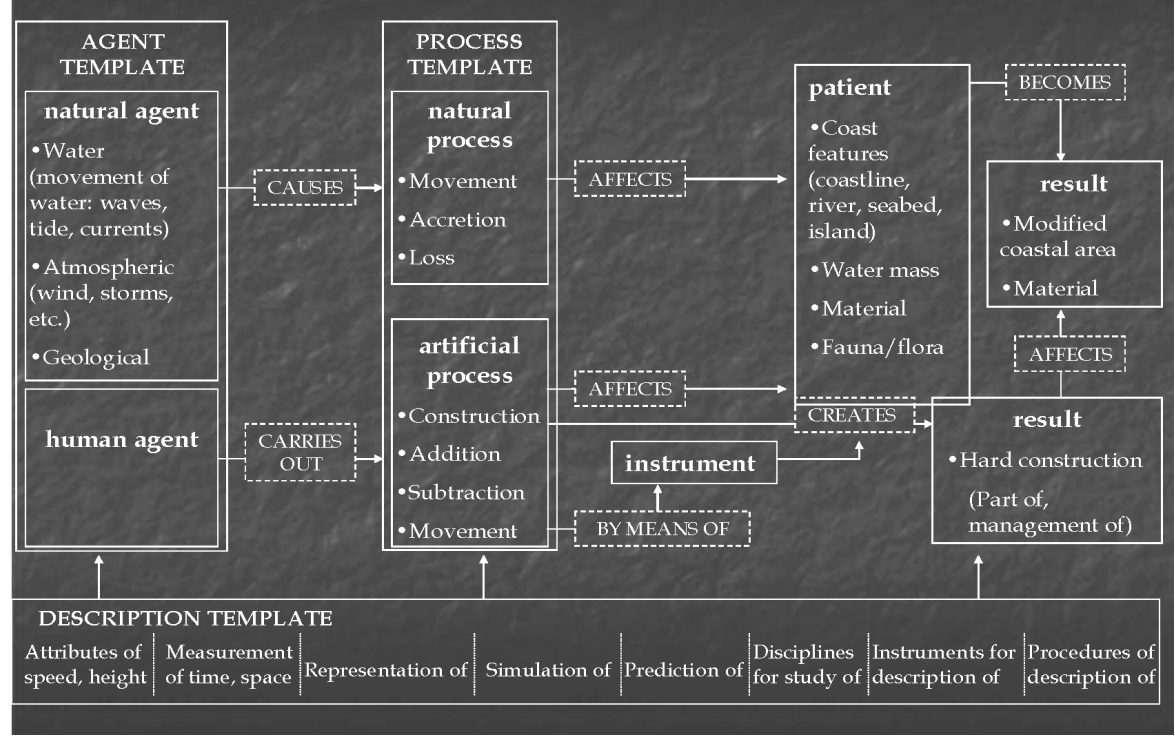

Figure 1. Coastal Engineering Event

cal place or environmental entity, thus producing a certain result that is often a modification in the affected entity.

The study of corpus data (in this case, concordances from specialized language texts) is very informative of the attributes of erosion as a process as well as its relations to other entities in the same domain. These attributes will constitute its definition, map out its conceptual relations linking it with other concepts, and also give information about its combinatory potential in one or various languages. By analyzing concordances the following information about erosion comes to light:

Erosion is a process:

(1) dies is a result of soil weathering and erosion processes. Excessive loading of

Erosion has a duration that can be short, medium, or long:

\begin{tabular}{|ll|}
\hline (2) & a community exhibits greater long-term erosion or accretion: exposure to high- \\
\hline (3) & F. \& Balasch, J. C. (1988). Medium-term erosion rates in a small scarcely vegeta \\
\hline (4) & as subject to both long- and short-term erosion, and understanding the causes of \\
\hline
\end{tabular}


Erosion is a time-dependent process and thus, time is present either by making reference to periods or episodes or specifying its seasonal nature:

Erosion measured in terms of time

(5) t a multiple change of accumulation and erosion periods, which reflects tectonic

Erosion according to the season when it occurs

(6) the contrast between summer and winter erosion rates is stark. Predicted values

(7) of summertime deposition and wintertime erosion ([Lee et al (1999)]). This type

Erosion can be classified according to the affected entity, which can either be a geographical location or marine fauna:

geographical location

(8) ): Coastal submergence and marsh fringe erosion. Journal of Coastal Research, 2(

(9) Processes and mechanisms of river bank erosion. In: R.D. Hey, J.C. Bathurst and

(10) impact of afforestation on stream bank erosion and channel form. Earth Surface

(11) , severity, and causes of coastal bluff erosion on the Cape Cod Bay shore of Tru

marine fauna

(12) see ICES, 1996) 2.1. Fin erosion Fin erosion is a pathological symptom common

Erosion is a process with spatial movement and directionality:

(13) $\mathrm{r}$ on Cape Cod Bay resulted in downdrift erosion for approximately 5,600 linear $\mathrm{f}$

(14) eam is near base level 1. Downward erosion is less dominant 2. Stream

(15) e estudio Rainfall (1/m2) and vertical erosion/acretion (cm) in Enmedio Island

Erosion is a process induced by a natural or human agent:

(16) iglacial environments: nivation; eolian erosion and deposition; and fluvial eros

(17) ited sediments from wind, water, or ice erosion. Given more time, these soils wi

(18) urbances, for instance by flood-induced erosion, redistribution of sediment or a

(19) e most important cause of human-induced erosion is interruption of sediment sour

(20) stal bluffs and episodic, storm-induced erosion of dunes and barrier beaches. A

(21) y 24 acres per year, while wave-induced erosion is approximately nine acres. Ac

This basic information about erosion is activated in the creation of the more specific terms that appear in the corpus, and which are hyponyms of erosion. These complex nominal forms are in reality compressed propositions, which have their own syntax. In their extended form, they would be the following: 
(22)

\begin{tabular}{|l|l|l|l|}
\hline Term & verb & Agent $($ Arg1) & Result (Arg2) \\
\hline storm-induced erosion & INDUCE & Storm & erosion \\
\hline Human-induced erosion & INDUCE & Humans & erosion \\
\hline wave-induced erosion & INDUCE & Wave & erosion \\
\hline
\end{tabular}

(23)

\begin{tabular}{|l|l|l|l|}
\hline Term & verb & Process (Arg1) & Location (Arg2) \\
\hline river bank erosion & OCCUR & Erosion & river bank \\
\hline marsh fringe erosion & OCCUR & Erosion & marsh fringe \\
\hline Coastal bluff erosion & OCCUR & Erosion & coastal bluff \\
\hline
\end{tabular}

These propositional representations can be activated in different ways, depending on the language involved and its rules for term formation. Such argument constructions provide the basic means of clausal expression in a language. For example (22) is an example of the construction: X causes $\mathrm{Y}$. Such constructions can be regarded as basic units of language. According to Goldberg (1995: 5):

In particular, constructions involving basic argument structure are shown to be associated with dynamic scenes: experientially grounded gestalts, such as that of someone volitionally transferring something to someone else, someone causing something to move or change state, someone experiencing something, something moving, and so on.

She proposes that the basic clause types of a language form an interrelated network, with semantic structures paired with particular forms in as general a way as possible. This is extremely useful in the analysis of syntax in specialized language texts, and in the specification of definitional templates.

Accordingly, the organization of information encoded in definitions can be structured in regards to its perceptual salience as well as its relationship to information configurations in the definitions of other related concepts within the same category (Faber et al. 2001; Faber 2002). Martin (1998) underlines the fact that frames as definition models offer more consistent, flexible, and complete representations.

\subsubsection{Use of images}

Another important aspect of frame-based terminology is that it has the virtue of dealing with the role of images in the representation of specialized concepts. It explains how the linguistic and graphical description of specialized 
entities are linked, and can converge to highlight the multidimensional nature of concepts as well as the conceptual relations within a specialized domain (Faber et al. 2007). It advocates a multimodal conceptual description in which the structured information in terminographic definitions meshes with the visual information in images for a better understanding of complex and dynamic concept systems.

Traditionally, images have been classified according to their morphology in categories of photographs, drawings, animations, videos, diagrams, charts, graphics, schemes, views, etc. (Darian 2001; Monterde 2002). However, it is more useful to categorize images in terms of their most salient functions (Anglin et al. 2004) or in terms of their relationship with the real-world entity that they represent. The typology of images is based on the criteria of iconicity, abstraction and dynamism as ways of referring to and representing specific attributes of specialized concepts (Prieto Velasco 2005):

- Iconic images resemble the real-world object represented through the abstraction of conceptual attributes in the illustration.

- Abstraction in an illustration is a matter of degree, and refers to the cognitive effort required for the recognition and representation of the concept thus represented (Levie \& Lentz 1982; Park \& Hopkins 1993; Rieber 1994).

- Dynamism implies the representation of movement (i.e. video and animation, as well as images showing different stages of a superordinate process respectively). However, such a representation need not include explicit movement if it illustrates the succession of discrete steps that make up the process.

In this way frame-based terminology endeavors to give a full accounting of the information necessary to fully describe a term, and which should be included in fully specified terminological entry.

\section{Bibliography}

ANGLin, G.; H. Vaez \& K. Cunningham. (2004) "Visual representations and learning: the role of static and animated graphics". In: Jonassen, D. (ed.) Handbook of Research on Educational Communications and Technology. Hillsdale, NJ: Lawrence Erlbaum. pp. 755-794.

AtKINS, S.; M. Rundell \& S. Hiroaki. (2003) "The contribution of Framenet to practical lexicography". International Journal of Lexicography 16 (3). pp. 334-357.

BARSALOU, L. W. (2003) "Situated simulation in the human conceptual system". Language and Cognitive Processes 18. pp. 513-562. 
BOUlAngER, J. C. (1991) "Une lecture socioculturelle de la terminologie". Cahiers de Linguistique Sociale 18. pp. 13-30.

BOWKer, L. \& M. L’Homme. (2004) "Ingrid Meyer, Terminologist (1957-2004)". Terminology 10:2. pp. 183-188.

BOWKER, L. \& I. Meyer. (1993). "Beyond 'textbook' concept systems: handling multidimensionality in a new generation of term banks". In: Schmitz, K.D. (ed.), TKE'93: Terminology and Knowledge Engineering, Frankfurt: Indeks Verlag. pp. 123-137.

Cabré Castellvi, M. T. (1999) Terminology. Theory, Methods, Applications. Translated by Janet Ann DeCesaris. Amsterdam: John Benjamins.

Cabré Castellví, M.T. (2000a) "Elements for a theory of terminology: Towards an alternative paradigm". Terminology 6(1). pp. 35-57.

Cabré Castellví, M. T. (2000b) "Sur la représentation mentale des concepts: bases pour une tentative de modélisation”. In: Béjoint, H. \& P. Thoiron (eds.) Le sens en terminologie. Lyon: Presses Universitaires de Lyon. pp. 20-39.

Cabré Castellví, M. T. (2001a) "Sumario de principios que configuran la nueva propuesta teórica”. In: Cabré, M. T. \& J. Feliu (eds.) La terminología científicotécnica: reconocimiento, análisis y extracción de información formal y semántica (DGES PB96-0293). Barcelona: Institut Universitari de Lingüística Aplicada. Universitat Pompeu Fabra. pp. 17-26.

Cabré Castellví, M. T. (2001b) "Consecuencias metodológicas de la propuesta teórica (I)”. In: Cabré, M. T. \& J. Feliu (eds.) La terminología científico-técnica: reconocimiento, análisis y extracción de información formal y semántica (DGES PB96-0293). Barcelona: Institut Universitari de Lingüística Aplicada. Universitat Pompeu Fabra. pp. 27-36.

Cabré Castellví, M. T. (2003). "Theories of terminology: their description, prescription and explanation”. Terminology 9(2). pp. 163-199.

Cabré Castellví, M. T. \& J. Feliu (eds.) (2001a) Terminología y cognición: II Simposio Internacional de Verano de Terminología (13-16 de julio 1999). Barcelona: Institut Universitari de Lingüística Aplicada.

Cabré Castellví, M. T. \& J. Feliu (eds.) (2001b) La terminología científico-técnica: reconocimiento, análisis y extracción de información formal y semántica. Barcelona: Institut Universitari de Lingüística Aplicada.

Cabré Castellví, M. T.; J. Freixa; M. Lorente \& C. Tebe. (1998). "La terminologia hoy: replanteamento o diversificacion. Terminologia e integracao". Organon, 12(26). pp. 33-41.

CROFT, W. (1993) "The role of domains in the interpretation of metaphors and metonymies". Cognitive Linguistics 4(4). pp. 335-370.

DARIAN, S. (2001) "More than meets the eye: the role of visuals in science textbooks". LSP \& Professional Communication 1(1). pp. 10-36. 
Evans, V. \& M. Green. (2006) Cognitive Linguistics: An Introduction. Edinburgh: Edinburgh University Press.

FABER, P. (2002) "Terminographic definition and concept representation". In: Maia, B. (ed.) Training the Language Services Provider for the New Millennium. Oporto (Portugal): University of Oporto. pp. 343-354.

FABER, P. \& C. Jiménez Hurtado (eds.) (2002) Investigar en terminología. Granada: Comares.

Faber, P.; P. León Araúz; J. A. Prieto Velasco \& A. Reimerink. (2007) “Linking images and words: the description of specialized concepts". International Journal of Lexicography 20. pp. 39-65.

FABER, P.; C. López Rodríguez \& M. I. Tercedor Sánchez. (2001) "Utilización de técnicas de corpus en la representación del conocimiento medico". Terminology 7:2. pp. 167-197.

FABER, P. \& R. Mairal. (1999) Constructing a Lexicon of English Verbs. Berlin: Mouton de Gruyter.

FABER, P.; C. Márquez Linares \& M. Vega Expósito. (2005). "Framing Terminology: A Process-Oriented Approach". META 50 (4). CD-ROM.

Faber, P.; S. Montero Martínez; M. R. Castro Prieto; J. Senso Ruiz; J. A. Prieto Velasco; P. León Arauz; C. Márquez Linares \& M. Vega Expósito. (2006) "Process-oriented terminology management in the domain of Coastal Engineering”. Terminology 12:2. pp. 189-213.

FElBer, H. (1984) Terminology Manual. París: UNESCO \& INFOTERM.

FERnANDEZ, M.; A. Góméz-Pérez \& N. Jurista. (1997) "METHONTOLOGY: From ontologica art towards ontological engineering workshop on Ontological Engineering". Spring Symposium Series. AAAI 97, Stanford, USA.

FILLMORE, C. J. (1976) "Frame semantics and the nature of language". In: Harnad, S. R.; H. D. Steklis \& J. Lancaster (eds.) Origins and Evolution of Language and Speech. Annals of the NY Academy of Sciences, 280. pp. 20-32.

Fillmore, C. J. (1982) "Frame semantics". In: The Linguistic Society of Korea (ed.) Linguistics in the Morning Calm. Seoul: Hanshin. pp. 111-137.

FILlmore, C. J. (1985) "Frames and the semantics of understanding". Quaderni di Semantica. 6 (2). pp. 222-254.

FILlmore, C. J. \& S. Atkins. (1992) "Towards a frame-based organization of the lexicon: The semantics of RISK and its neighbors". In: Lehrer, A. \& E. Kittay (eds.) Frames, Fields, and Contrast: New Essays in Semantics and Lexical Organization. Hillsdale, NJ: Lawrence Erlbaum. pp. 75-102.

FILlmoRE, C. J. \& S. Atkins. (1998) "FrameNet and lexicographic relevance". In: Proceedings of the ELRA Conference on Linguistic Resources, Granada. pp. 417-423.

FILlmore, C. J.; C. R. Johnson \& M. Petruck. (2003) "Background to Framenet". International Journal of Lexicography 16(3). pp. 235-250. 
Fillmore, C. J.; M. Petruck; J. Ruppenhofer \& A. Wright. (2003) "Framenet in action: the case of attaching". International Journal of Lexicography 16 (3). pp. 298-332.

GAUDIN, F. (1991) "Terminologie et travail scientifique: mouvement des signes, mouvement des connaissances". Cahiers de linguistique sociale 18. pp. 111-132.

Gaudin, F. (1993) Pour une socioterminologie: Des problèmes pratiques aux pratiques institutionnelles. Rouen: Publications de l'Université de Rouen.

GAUdin, F. (2003). Socioterminologie: Une approche sociolinguistique de la terminologie. Bruxelles: Duculot.

GEERAERTS, D. (1995) "Representational models in cognitive semantics". Folia Linguistica: Acta Societatis Linguisticae Europaeae XXIX(1-2). pp. 21-41.

GoldberG, A. (1995) A Construction Grammar approach to argument structure. Chicago: University of Chicago Press.

GoldberG, A. (1998) "Patterns of experience in patterns of language". In: Tomasello, M. (ed.) The New Psychology of Language. Hillsdale, NJ: Lawrence Erlbaum. pp. 203-219.

Gregory, M. \& S. Carroll. (1978) Language and Situation. London: Routledge \& Kegan Paul.

GRINEV, S. \& I. Klepalchenko. (1999) "Terminological approach to knowledge representation”. In: P. Sandrini (ed.). TKE '99: Proceedings of the 5th International Congress on Terminology and Knowledge Engineering. Innsbruck, Austria. Vienna: TermNet. pp.147-151.

GUESPIN, L. (1991) "La circulation terminologique et les rapports entre science, technique et production". Cahiers de Linguistique Sociale 18. pp. 59-79.

KerRemans K.; R. Temmerman \& J. Tummers. (2004). "Discussion on the Requirements for a Workbench supporting Termontography". In: WiLliams, G. \& S. Vessier (eds.) Proceedings of the XIth Euralex International Congress 2004, 6-10 July, Lorient, France. Lorient: Université de Bretagne-Sud. pp. 559-570.

Kerremans, K.; R. Temmerman \& G. Zhao. (2005) "Terminology and Knowledge Engineering in Fraud Detection". In: Proceedings of the International conference on Terminology and Knowledge Engineering. Copenhagen, 16th - 19th August 2005.

LAKoff, G. (1987) Women, Fire, and Dangerous Things. Chicago: University of Chicago Press.

LANGACKER, R. (1987) Foundations of Cognitive Grammar. Stanford: Stanford University Press.

LANGACKer, R. (1991) Concept, Image and Symbol. The Cognitive Basis of Grammar. Berlin: Mouton. 
LANGACKER, R. (1997) "The contextual basis of cognitive semantics". In: Nuyts, J. \& E. Pederson (eds.) Language and Conceptualization. Cambridge: Cambridge University Press. pp. 227-252.

LANGACKER, R. (2000) "Estructura de la cláusula en la gramática cognoscitiva". Revista Española de Lingüística Aplicada, Vol. Monográfico (2000). pp. 19-65.

LEVIE, W. H. \& R. Lentz. (1982) "Effects of text illustrations: a review of research". Educational Communication and Technology Journal 30. pp. 195-232.

LHomme, M. C. (2003) "Capturing the lexical structure in special subject fields with verbs and verbal derivatives: a model for specialized lexicography". International Journal of Lexicography 16(4). pp. 403-422.

MAIRAL, R. \& P. Faber. (2002) "Functional grammar and lexical templates". In: Mairal, R. \& M. J. Pérez (eds.) New Perspectives on Argument Structure in Functional Grammar. Berlin: Mouton de Gruyter. pp.39-94.

MARTIN, W. (2006) "Frame-based lexicons and the making of dictionaries". In: Corino, E.; C. Marello \& C. Onesti (eds.) Proceedings of the Twelfth EURALEX International Congress. Accademia della Crusca, Università di Torino. Alessandria: Edizioni dell'Orso. pp. 281-293

MEYER, I.; L. Bowker \& K. Eck. (1992) "COGNITERM: An experiment in building a knowledge-based term bank". In: Proceedings of the Fifth EURALEX International Congress. Tampere, Finland. pp. 159-172.

MeYer, I.; K. Eck \& D. Skuce. (1997). "Systematic concept analysis within a knowledge-based approach to terminology". In: Wright, S.E. \& G. Budin (eds.) Handbook of Terminology Management. Amsterdam/Philadelphia: John Benjamins. pp. 98-118.

MeYer, I. \& B. McHaffie. (1994). "De la focalisation à l'amplification: nouvelles perspectives de représentation des données terminologiques". In: Clas, A. $\&$ P. Bouillon (eds.) TA-TAO: Recherches de pointe et applications immédiates. Montréal: Les Presses de l'Université de Montréal. pp. 425-440.

Monterde Rey, A. M. (2004) "La importancia de la ilustración para la traducción técnica". In: Gonzalo García, C. et al. (eds.) Manual de Documentación, Terminología y Traducción especializada. Madrid: Arco/Libros. pp. 259-274.

PARK, O. \& R. Hopkins (1993). "Instructional conditions for using animated visual displays: A review”. Instructional Science 22. pp. 1-24.

Pavel, S. \& D. Nolet. (2001) Précis de terminologie/The Handbook of Terminology. Adapted into English by Christine Leonhardt. Hull: Public Works and Government Services of Canada.

Pihkala, T. (2001) "Socioterminology". Terminfo 1/2001 — Summaries, Nordterm 2001. [Available at http://www.tsk.fi/fi/ti/ti101_teksti.html].

Prieto Velasco, J. A. (2005) "El papel de la información gráfica en la descripción de conceptos en la Ingeniería de puertos y costas". Paper presented at the Jornadas Hispano-Rusas. Granada, Spain. 
RiEBER, L P. (1994) Computers, Graphics, and Learning. Madison, WI: Brown \& Benchmark.

Rosch, E. (1978) "Principles of categorization". In: Rosch, E. \& B.B. Lloyd (eds.) Cognition and Categorization. Hillsdale, N.J: Erlbaum. pp. 27-48

Ruppenhofer, J.; M. Ellsworth; M. R. L. Petruck; C. R. Johnson \& J. Scheffdzyk. (2006) "FrameNet II: Extended Theory and Practice". [Available at: http:// framenet.icsi.berkeley.edu/index.php?option=com_wrapper\&Itemid=126]

SKUCE, D. \& T. C. Lethbridge. (1995) "CODE4: A unified system for managing conceptual knowledge". International Journal of Human-Computer Studies 42. pp. 413-451.

SMITH, E. E. (1978) "Theories of semantic memory". In: Estes, W.K. (ed.) Handbook of learning and cognitive processes, vol. 6. Hillsdale NJ: Lawrence Erlbaum. pp. 1-56.

StAmbuk, A. (1998) "Metaphor in scientific communication". META XLIII 3. pp. $1-7$.

STREHLOW, R. (1993) "Terminological standardization in the physical sciences". In: Sonneveld, H. B. \& K. L. Loening (eds.) Terminology: Applications in Interdisciplinary Communication. Amsterdam/Philadelphia: John Benjamins. pp.127-140.

SuRE, Y. \& R. Studer. (2003) "A methodology for ontology-based knowledge management”. In: Davis, J.; D. Fensel \& F. Van Harmelen (eds.) Towards the Semantic Web. Ontology-Driven Knowledge Management. Chichester, UK: John Wiley \& Sons. pp. 33-46.

TEMmerman, R. (2006) "Sociocultural situatedness of terminology in the life sciences: The history of splicing”. In: Zlatev, J.; T. Ziemke; R. Frank \& R. Dirven (eds.) Body, Language and Mind. Vol II. Interrelations between Biology, Linguistics and Culture. Berlin: Mouton de Gruyter.

TEMmerman, R. (1997) "Questioning the univocity ideal. The difference between sociocognitive Terminology and traditional Terminology". Hermes. Journal of Linguistics 18. pp. 51-91.

Temmerman, R. (2000) Towards New Ways of Terminology Description. Amsterdam/Philadelphia: John Benjamins.

Temmerman, R. (2001) "Sociocognitive terminology theory". In: Cabré, M.T. \& J. Feliu (eds.) Terminología y Cognición. Barcelona: Universitat Pompeu Fabra. pp. 75-92.

Temmerman, R. \& K. Kerremans. (2003). "Termontography: Ontology Building and the Sociocognitive Approach to Terminology Description". Prague CIL17 Conference. [Available at: http://www.hf.uib.no/forskerskole/temmerman_art_prague03.pdf] 
Temmerman, R.; K. Kerremans \& V. Vandervoort. (2005) "La termontographie en contexte(s)". In: Actes des Septièmes Journées scientifiques du Réseau Lexicologie, terminologie, traduction, Brussels, Belgium.

Wright, S. E. \& G. Budin. (2001) Handbook of Terminology Management. Vol. 1 and 2. Amsterdam: John Benjamins.

WÜSTER, E. (1979) Introducción a la Teoría General de la Terminología y a la Lexicografía Terminográfica. Barcelona: IULA, 1998.

WÜSTER, E. (1968) The Machine Tool. An interlingual dictionary of basic concepts. London: Technical Press. 